\title{
Comparing ENQA, British, German \& Albanian Standards of Quality in Higher Education
}

\author{
By Jona Hoxhaj ${ }^{1}$, Dr. Eglantina Hysa ${ }^{2}$
}

\begin{abstract}
The development and enhancement of life conditions and standards of living, which are enabled by progress in technology, social life, cultural life, scientific researches and new inventions is very tightly and positively connected with higher education. The desire to have better life conditions has stimulated people toward new technological and social inventions which have made life easier. This desire have put people in an infinity road of continuously developing new standards of education to have a more qualitative education leading to those nowadays technological and social progresses making world a fast changing environment. This cycle is bringing us year by year a more qualitative education system based on the competition of universities, states and continents to be the first choice of the students around the world. Universities and Academics in collaboration with university accreditation agencies and universities quality control organizations are working so hard to maintain and increase standards of quality in higher education in their hometowns. Maintaining and assuring qualitative education is a basic point in order to have credibility in the educative institutions and national educative system. This study is covering the examination of the quality of standards in higher education in European countries which are part of ENQA having a harmonized higher system of education for more than 10 years. Also a detailed study of German higher education system, as an example of a country being part of ENQA, examining standards and criterion evaluation of the quality of higher education in this country. The study except of examination will compare these standards in ENQA countries with British and Albanian quality standards in higher education. Britain's organization which is covering the evaluation of the higher education system and controlling the fulfillment of the standards and criterion is QAA and it has slightly different standards when compared to ENQA. In this study it has been investigated the whole higher education system of the region and the effectiveness and quality of education in the universities and colleges of UK. Albania is part of ENQA from 18 September 2003 (Golloshi, 2013) when the Bologna Declaration was signed. But Albania because of being a developing country is having difficulties in accomplishing all the standards and criterion as European Countries. This decade has been very crucial for changes in education system in Albania and the system is being developed year by year. The study examines and compares the fulfillment and quality of standards in Albania with those of other European countries and also will compare the higher education system of the small developing country of Albania with those of Great Britain.
\end{abstract}

Keywords: Higher Education, Quality, Standards, Criterion, ENQA, Britain, Albania

\section{Introduction}

In nowadays society higher education is being more and more a very crucial ticket for being acceptable in social life and environment. Even that the societies are different and are continuously developing and have diverse perception based on referenced knowledge's toward the higher education they are still all together supporters of education. Therefore as this study will be mostly based on assurance of quality in higher education and comparing different in educative systems in some areas the main issue to be disused is; if the higher education is perceived in all 
those mentioned above countries same and are those countries able to include and implement in their areas the same European standards of education.

The majority of the countries in European continent are divided in groups according to their economic and social conditions. The high standard countries in economy are supporting those developments with very qualitative social life which is being possible from education and welfare. The middle standard countries are again countries giving very much support to educative developments as they are struggling for excellence in an environment with a very tough competition in Europe for production, innovation and economic development, which can be achieved only by supporting and assuring qualitative education. Countries in transition which are waiting in the front door to be part of European Union are the ones that have to assure quality in education in order to be accepted in EU and are continuously controlled by accreditation agencies and international agencies. It can be concluded that all the European countries are working to assure the quality but the paper offers a more detailed approaches of some countries toward quality assurance and qualitative higher education.

Role of higher education in today's world is the main focus of all the governments being elected. The only way to be the choice of citizens is proving that education will always be the apple in their eye. The demand for qualitative and standardized educative system is increasing day by day as globalization and mobilization in other fields is being achieved. Parts of higher education are not only universities but it covers sharing academic information, research paper workings, colleges and gain of professional skills.

\section{ENQA, European Network for Quality Assurance}

The idea of creating an organization for standardization of educative system in European area has its roots in 1994-1995 when the first Pilot Project for Evaluating Quality in Higher Education was presented in front of Council of Ministers of Europe. This has had the main focus to share and develop experience in quality assurance in higher education. (Official Website of ENQA, 2014)

"Following the Recommendation of the Council (98/561/EC of 24 September 1998) on European co-operation in quality assurance in higher education and the Bologna, ENQA was established in 2000 as the European Network for Quality Assurance in Higher Education to promote European co-operation in the field of quality assurance.

In 2004 the Network was transformed into the European Association for Quality Assurance in Higher Education (ENQA).” (Official Website of ENQA , 2014)

\subsection{The history of success and Future strategic vision}

The educative system before 15 year was very different in all the countries in Europe. The need to have a consolidated system and an organization to assure quality was firstly put on focus by European Council of Minister under the Dutch presidency in 1991. In that time a survey was conducted which concluded that very few countries had external quality assurance arrangements and the Commission therefore found a need to arrange some quality assurance projects. The European Report which was approved in 1994 and put in action from 1995 have been considered by many institutions, Ministries and other state institutions in more than 17 countries covering nearly 46 institutions.

The official starting point of this organization was the 24th of September 1998 when the Council's Recommendation was presented for co-operation of European countries for Quality assurance in Higher Education. "This Recommendation invited Member States to "promote co-operation between the authorities responsible for quality assessment or quality assurance in higher education and promote networking". Moreover, the Commission "encouraged the co-operation between the 
authorities responsible for quality assessment and quality assurance in higher education, also involving organizations and associations of higher education institutions with European remit which is the necessary experience in quality assessment and quality assurance"." (Thune, 2010, p. 9)

"On 28-29 March 2000, representatives of quality assurance agencies in the EU/EEA, of ministries responsible for higher education in the EU and EFTA/EEA-countries, and of associations of higher education met in Brussels for the launch conference of ENQA." (Thune, 2010). Christian Thune was appointed as Chairman of ENQA for the following three years but it ended up as a chairman for the next five years.

From the times that the organization was founded the main conferences which have clarified the pathway of ENQA and have helped in the development of it are Prague (2001), Berlin (2003), Bergen (2005), London (2007), Leuven/ Louvain-la-Neuve (2009) and Budapest and Vienna (2010). (Editors: Fiona Crozier, Nathalie Costes, Paula Ranne and Maria Stalter, 2010)

Now ENQA is the main source of information for quality in European level, quality assurance standards of ENQA are the main instruments to achieve development and accountability in higher education and in order to achieve the main aim of having quality assurance in all the areas of Europe ENQA needs to include all the countries and have active membership. ENQA is the representative of all quality agencies in EU area and it should be the main ambassador of presenting the quality in higher education as a culture of its member states.

ENQA's strategic goals, vision and mission are:

VISION

European higher education committed to a culture of quality.

MISSION

To contribute significantly to the maintenance and enhancement of the quality of European higher education at a high level, and to act as a major driving force for the development of quality assurance throughout the European Higher Education Area.

GOALS

1. Association and membership issues

ENQA aims at comprising quality assurance agencies from all countries in the EHEA in order to be as inclusive as possible.

ENQA aims at an intensive involvement of members in internal discussion and decision-making processes.

ENQA aims at offering services for members that help them to develop further.

2. Policy-making role

ENQA aims at being a main political actor with material influence on decision-making processes at the European level to deliver on the core values of quality assurance as enunciated in the ESG.

3. Development of Quality Assurance in Europe

ENQA aims at developing quality assurance processes as core instruments for both enhancement and accountability purposes.

ENQA aims to be recognized as the core source of expertise and information in the field of quality assurance at the European level.

4. Co-operation with other organizations

ENQA aims at being recognized as the preferred partner in all matters relating to the development of quality assurance at the European level. Source: (Official Website of ENQA, 2014)

\subsection{European standards and guidelines for quality assurance of higher education}

This section covers a very wide range of standards and guidelines for quality assurance in higher education used by ENQA and implemented by the countries being part of it. The section 
is completely taken as reference from the "Report on Standards and Guidelines for Quality Assurance in the European Higher Education Area" which is published by European Association for Quality Assurance in Higher Education in 2009 in Helsinki. (report, 2009)

Standards and guidelines for quality assurance in higher education are separated in 3 major parts which have subsections in order to better clarify the standards. The first part is related with internal quality assurance in the institutions, the second part with external quality assurance in higher education and the third one covers standards for external quality assurance agencies.

Part 1: European standards and guidelines for internal quality assurance within higher education institutions:

1.1 Policy and procedures for quality assurance: Every institution should have policies and procedures for quality assurance; in order to achieve it they should prepare strategic plans for quality enhancement.

1.2 Approval, monitoring and periodic review of programs and awards: All the programs and awards should be approved, monitored and reviewed by a special standard from the institutions.

1.3 Assessment of students: Students should be assessed using published criteria, regulations and procedures which are applied consistently.

1.4 Quality assurance of teaching staff: Teachers should be qualified and competent.

1.5 Learning resources and student support: Each program offered by the institution should be supported by adequate resources

1.6 Information systems: Institutions should ensure that they collect, analyze and use relevant information for the effective management of their programs of study and other activities.

1.7 Public information: Institutions should update and make public information about the programs they offer in qualitative and quantitative.

Part 2: European standards for the external quality assurance of higher education: The system of external quality assurance should be based on use of internal quality assurance procedures in order to develop adequate external quality assurance processes. All the decisions should be based on some published criteria and the processes should fit on with the aim and the goals. Reporting of events and decisions should not be excluded, the procedures should be followed, periodic reviews which all will be a cyclic evaluation of external quality controlling. Also very important is that the quality assurance agencies should produce summery reports based on the evaluations, assessments and general findings.

2.1 Use of internal quality assurance procedures

2.2 Development of external quality assurance processes:

2.3 Criteria for decisions:

2.4 Processes fit for purpose:

2.5 Reporting:

2.6 Follow-up procedures:

2.7 Periodic reviews:

2.8 System-wide analyses:

The above mentioned steps describe the process of external quality assurance of higher education. Part 3: European standards for external quality assurance agencies

3.1 Use of external quality assurance procedures for higher education: External quality assurance agencies should prove that there is present and effective external quality assurance in higher education institutions.

3.2 Official status: Agencies should be formally recognized by competent public authorities in the European Higher Education Area as agencies with responsibilities for external quality assurance and should have an established legal basis

3.3 Activities: Agencies should undertake external quality assurance activities

3.4 Resources: Agencies should have adequate and proportional resources, both human and 
financial

3.5 Mission statement: Agencies should have clear and explicit goals and objectives for their work 3.6 Independence: Agencies should be independent to the extent both that they have autonomous responsibility for their operations and that the conclusions and recommendations made in their reports cannot be influenced by third parties such as higher education institutions, ministries or other stakeholders.

3.7 External quality assurance criteria and processes used by the agencies: The processes, criteria and procedures used by agencies should be pre-defined and publicly available. These processes will normally be expected to include:

- a self-assessment or equivalent procedure by the subject of the quality assurance process;

- an external assessment by a group of experts, including, as appropriate, (a) student member(s), and site visits as decided by the agency;

- publication of a report, including any decisions, recommendations or other formal outcomes;

- a follow-up procedure to review actions taken by the subject of the quality assurance process in the light of any recommendations contained in the report.

3.8 Accountability procedures: Agencies should have in place procedures for their own accountability. (P.7-9)

\subsection{Evaluation Methodology and 4 stage model of ENQA}

In Europe before 1998 there were many different methods used from all the nations in Europe. In 1998 study which included 18 countries concluded 4 types of evaluations: evaluation, accreditation, auditing and benchmarking combining them with the categories of focus: subject, program, institution or theme, combining the element-based method and focuses result in 16 different types of evaluation which are used to evaluate the quality assurance by agencies which are part of ENQA. Agencies in majority carry out more than one evaluation method. (Survey, 2003)

Evaluation: In this section evaluation is not used as the general term for the quality assurance evaluation but as a method. When it is combined with different focal points there are 4 different evaluations that are being used.

The types are: Evaluation of the subject, evaluation of an institution, evaluation of a program and evaluation of a theme. In the years when the survey was conducted countries were using only one focal point but they extended it during the years. Also because of the developments we can observe that different institutions are switching their methods from program oriented in 1990's they have broadened their methodologies. Some companies and institutions are even combining different evaluation types.

Accreditation: Is another used method for quality assurance which is very similar with evaluation as it is also using four-stage-model. It has been used primarily from Germany and Nordic Countries. But the survey gives some important characteristics which express the difference of evaluation with accreditation;

- Accreditation recognizes that a higher education course, program or institution meets a certain standard, which may be either a minimum standard, or a standard of excellence

- Accreditation therefore always involves a bench-marking assessment

- Accreditation findings are based on quality criteria, never on political considerations.

- Accreditation findings include a binary element, being always either yes or no. (Survey, 2003, pp. 19, 20)

There are states that already have Accreditation agencies and there are others that are planning to have agencies for accrediting institutions, programs or even other agencies.

Audit: Is internal control of institutions, programs and different subjects. It is done to have a 
continues control over the activities done. It evaluates the strengths and weaknesses of the organization. Auditing is not very common for European quality assurance.

Benchmarking: As it was mentioned above for accreditation also benchmarking can be understood as an element of evaluation.

"In the present study, benchmarking is defined as a method, whereby a comparison of results between subject, programs, institutions of themes leads to an exchange of experiences of best practice." (Survey, 2003, p. 20)

The main difference of accreditation and benchmarking is that; accreditation is based on threshold level in the other hand benchmarking is based on excellence level. Benchmarking is not very widely used as primary method of evaluation by institutions.

\section{The 4-Stage Model}

Variety of methodologies that are being developed in evaluation of the QA has made it necessary to use the 4 stage model in order to be sure that external experts control the agencies and self evaluations are taking place periodically.

This model has been presented from 1998 in the pilot project:

- Autonomy and independence in terms of procedures and methods concerning quality evaluation both from government and from institutions of higher education,

- Self-assessment,

- External assessment by peer-review group and site visits, and

- Publication of a report

This 4-stage-model that has been mentioned in the pilot project and has been part of Council Recommendation is still features in European Quality Assurance.

\section{The Case of Germany}

\subsection{Quality Standards in Higher Education in accordance with ENQA}

Higher institutions in Germany are autonomous bodies, self governing and develop and prepare their study programs according to their goals and vision. But the rules and regulations must be in line with laws of the state and approved by State Minister.

As it was mentioned above the debate of evolution and improvement in quality standards has it roots very early and it was not Germany the place where it started. In Germany this debate was firstly opened in 1980's, later than in other European countries.

The controlling body of Higher education institutions in Germany is Land Ministry of Science and Research. The external periodical evaluation of higher education institutions that is done in all the countries is done also in Germany by specialized agencies for evaluation.

The main conference that has put the roots of QA in Germany was the Standing Conference of the Ministers of Education and Cultural Affairs of the Lander (Kultusminsterkonferenz-KMK) in October 1998. In which was established a Foundation for the Accreditation of Study Courses in Germany. The main responsibilities of this foundation are; accrediting the agencies which are responsible of external evaluation of higher education institutions, binding the guidelines and regulation that have been determined in Lander into the guidelines of these accreditation agencies and monitoring the accreditation processes undertaken from these agencies. (Editors; Brigitte Lohmar, Thomas Eckhardt , 2013). Accreditation system in Germany became permaanent in 1 January 2003.

The main objective of Accreditation Council in Germany as in all the European countries is to set minimum standards that agencies have to meet in order to win the status of authorized body to accredit the courses. Germany also uses acreditation as evaluation methodology. Accreditation system in Germany as its roots in 1980's. Steps of evaluation are; -Internal Evaluation; for each degree program University prepares a self-report describing the 
structure

-External evalution; a number of indpenndent peers judge the programs and outcomes of the courses in the university

-Follow up; quality assurance through evalution is not generally a selective procesure but a continouse process. University should continously improve the quality standards and shopuld be followed by the agency. (Mauro Bemardini, Francesca Ruffilli, 2006)

Evaluation is still a method used in Germany it has not been totally replaced in all institutions. Some HE institutions use the combination of evaluation and accreditation and some others use only evaluations methodology.

\section{QAA, Quality Assurance Agency for Higher Education in the United Kingdom}

Quality Assurance Agency, QAA is the main body of quality assurance in four parts of UK, which includes England, Wales, Scotland and Northern Ireland. It was established in 1997 in order to have a better control in quality of higher education in UK even thought quality assurance was existing before. QAA is owned by Universities UK, Universities Scotland, Higher Education Wales and the Standing Conference of Principals. It is independent from Government. (Quality Assurance Agency for Higher Education, 2005, p. 5)

\subsection{QAA and its role in the UK Higher Education System}

In four regions of UK higher education institutions are independent from government but most of them are partly founded by government, and established by Royal Charter or Legislation.

All the universities in UK area have their autonomy to decide on the courses and degrees according to their conditions of awarding. There are different type of HE; universities, university colleges and specialized institutions of $\mathrm{HE}$.

The types of qualification awarded by the higher education institutions in UK are; sub-degree and undergraduate and postgraduate degrees. The regulatory body of these issues is Framework for Higher Education Qualifications in England, Wales and Northern Ireland (FHEQ), which has been self certified as competent with the Framework for Qualifications of the European Higher Education Area, the qualification adapted as part of Bologna Process in 2009. Foundation designated degrees that made possible to educate people who are strongly oriented in the profession that they are going to do in the future. These were short cycle qualification degrees.

The main role of QAA is to have peer-reviews of higher education institutions by auditing. Information published by intuitions is also reviews in order to control the adequacy and accuracy. Standards are set by the institutions themselves based on general approaches of QAA. They must have external examination, reports, statuses and regulatory bodies based on national rules set by FHEQ. (ECCTIS)

Universities and other HE institutions are responsible for their quality processes and controlling the quality of their awards, QAA in the other side is responsible to make sure that these processes are being fulfilled by institutions and how much effective are those processes. QAA is the advocate of the public in UK as it stimulates quality standard to be maintained and improved. They periodically;

- conducting external reviews (including audit) in universities and colleges

- describing clear academic standards through the Academic Infrastructure

- advising government on applications for degree awarding powers and university title

- offering advice on academic standards and quality. (Quality Assurance Agency for Higher Education, 2005, p. 5)

HE institutions have to apply for the authority of giving degrees and be "awarded" with the name 
of university or university collage. And they have to achieve some set standards in order to keep those names after set periodical reviews of QAA.

\subsection{UK Academic Quality and standards of Higher Education}

QAA is responsible in collaboration with UK higher education sector be organize the Academic Infrastructure, which includes the frameworks for higher education qualifications, subject benchmark statements, program specifications and the Code of Practice. (Quality Assurance Agency for Higher Education, 2005, p. 10)

Frameworks are related with the qualification titles, UK has two major frameworks one for Scotland and one for England, Wales and Northern Ireland which is compatible with Bologna Process.

Subject benchmarking is part of PAR A in Quality Code and is related with the degrees in the specific areas that universities cover. It sets up standards for specific degrees. (Quality Assurance Agency, QAA, 2014)

"Subject benchmark statements are available for bachelor's degrees with honors and for master's degrees. There are also statements specifically for the health professions and for professional qualifications in Scotland." (Quality Assurance Agency, QAA, 2014)

Each university has its special program and gives specific information on their details about the program offered.

"Code of practice is a guideline on good practice about management of academic standards and quality for universities and colleges. It has 10 sections:

1. Postgraduate research programs

2. Collaborative provision

3. Students with disabilities

4. External examining

5. Academic appeals and student complaints on academic matters

6. Assessment of students

7. Program approval, monitoring and review

8. Career education, information and guidance

9. Placement learning

10. Student recruitment and admissions" (Quality Assurance Agency for Higher Education, 2005, p. 10 11)

\section{Standards of Higher Education in UK}

QAA's main goal is to safeguard and improve the quality of education in UK.

The Quality Code of UK is the standards that all higher education institutions are required to meet and is grouped in three parts; (Quality Assurance Agency, 2014)

Part A on academic standards

Part B on academic quality

Part $\mathrm{C}$ on information about higher education provision

PART A; is related with setting and maintaining academic standards. Academic standards are the minimum achievements that a student has to have in order to be acceptable for academic award.

Content;

Chapter A1: The national level

Chapter A2: The subject and qualification level

Chapter A3: The program level

Chapter A4: Approval and review

Chapter A5: Externality

Chapter A6: Assessment of achievement of learning outcomes

PART B; is related with Assuring and Enhancing Academic quality. It is concerned with the 
achievement of institutions to offer to their student's standardized opportunities. (Quality Assurance Agency, QAA, 2014)

Content;

Chapter B1: Program design, development and approval

Chapter B2: Recruitment, selection and admission to higher education

Chapter B3: Learning and teaching

Chapter B4: Enabling student development and achievement

Chapter B5: Student engagement

Chapter B6: Assessment of students and the recognition of prior learning

Chapter B7: External examining

Chapter B8: Program monitoring and review

Chapter B9: Academic appeals and student complaints

Chapter B10: Managing higher education provision with others

Chapter B11: Research degrees

PART C; it is related to information about higher education provision. It makes possible to third parties the information to be available, reliable and accessible with regulation. So it is about transparency. (Quality Assurance Agency, QAA, 2014)

Part C: Information about higher education provision

Standards are very important in HE, except to be set they have to be maintained. Also in UK each Institution has the special group of people and procedures that are responsible for maintaining and controlling these standards. In accordance with QAA, internal quality assurance is made up some steps internally controlled; Admissions policies, program approval and review, assessment regulations and mechanisms, monitoring and feedback processes, staff selection and development, staff appraisal, internal review. And they also have external examiners, who are independent actors assuring that standards set and operational processes are fair and regular.

\subsection{Evaluation Criteria and External Review}

QAA provides many types of reviews and it uses them in accordance with different factors, as the type of institutions and the type of qualification they offer.

Types of Reviews;

- Reviews of Higher education providers

- Reviews of higher education delivered in further education colleges

- Reviews of higher education delivered by private providers

- Reviews of higher education delivered overseas

- Reviews of professional programs (Quality Assurance Agency, QAA, 2014)

QAA uses a variety of methods for external review of $\mathrm{HE}$ but in general they follow similar outline; Self Evaluation, Peer Review and Publication of results. The detailed process is presented above;

Self Evaluation; When institutions are being prepared for external control they are producing a report on the efficiency and effectiveness of standards during the specific period.

Selecting Teams and Training teams; Peer review process is done from independent academicians that apply and are being selected from QAA to review institutions other than their working institution. They are being trained to have a more efficient review and control process.

Preparing for Reviews and Conducting Reviews; the reviews are made up of team's 4 to 6 people and universities are informed before about these reviews. The process is like auditing and controlling of the report and documents which support the claims in the report.

Publishing of Reports; Reports include the review findings and internal report. They are useful for all interested parties in HE cycle. QAA does not publish any ranking list of universities; they are published from different organizations which are based on different reports and findings. (Quality 
Assurance Agency for Higher Education, 2005)

Also subject level reviews which are useful only in England; Major review and Academic review of subjects.

\section{Regions of UK...}

The regions of UK have some different types of reviews;

"Higher Education Review

Higher Education Review is the review method for higher education institutions in England and Northern Ireland from 2013-14.

Institutional Review (Wales)

Institutional Review (Wales) is the review method for higher education institutions in Wales

Enhancement-led Institutional Review

Enhancement-led Institutional Review (ELIR) is the review method for higher education institutions in Scotland.

Higher Education Review: Wales

Higher Education Review: Wales is the review method for providers of higher education in Wales from 2014-15. It succeeds Institutional Review (Wales).

\section{Quality Assurance in Higher Education in Albania}

Quality assurance has become the mainstream in all the universities in Albania nowadays. It is a trend that has the roots on Bologna Declaration, which is the main turn in educative system in Albania. Bologna Process objective is to make the European HE market competitive in the world and to ensure qualitative education to its citizens in EU area. Unification of educative system in three cycles is the best choice in order to have easier transfers of students and acceptance of diplomas in all countries vice- versa.

The focus of Bologna process is "student- Scientific Community- Business Community" (Arjan Qefalia, Arbina Totoni , 2012, p. 264). Students are the main focus of any business because they are the customers of universities. Scientific Communities are important in researching and developing new opportunities and approaches to improvements in the world, they will be the pride of universities and business communities are important because it employs the graduates and finances activities. Universities have to have very good relation with businesses out there if they want to survive in the community of competition.

\subsection{Structure and characteristics of Higher Education in Albania}

Government and Parliamentary Bodies are the main actors in determining the educational policies in higher education, based on Constitution. Ministry of Education and Science and other local authorities are responsible with evaluating and ensuring if requirements of population are met in the field of education. (EACEA, 2012)

On $21^{\text {st }}$ of May 2007 The Law on Higher Education No 9741 has been changed. This law regulates the activities of universities and faculties.

In accordance with the laws, studies in Albanian universities can be full-time studies, part-time and distance studies. The degrees that are given in Albanian Universities are; Bachelor, Master of Science, Professional Master, Integrated studies and Doctorate study programs or long term specializations.

In Republic of Albania all the Universities and higher education institutions public or private prior to their issue of activities and issue of diplomas have to be accredited, in order to be able to have recognized diplomas for their gradated students by Republic of Albania.

PAAHE, Public Agency for Accreditation of Higher Education, is an independent body which is responsible for evaluation of the standards of HE institutions and for external audit. This process 
starts from the beginning when the institution applies to be opened/ licensing and during the years of existence. (EACEA, 2012)

Quality has become a very big concern for all $\mathrm{HE}$ institutions in Albania, all universities are competing to be on top of the rankings and win competitive advantage. Bologna Process is the main reason for the dramatic changes that have happened to higher education picture in Albania, 2012 was the big turn. The main objective of Albanian policies after adopting Bologna Process is to achieve European standards and quality. The standardization and reforms in education system accepted and implemented in all EHEA helps Albania to be comparable with European Countries in the educative system which also is an advantage in accepting diplomas of Albanian universities in EU area. (Dr. Tomi Treska, Dr. Erjona Canaj, 2013)

The main Bologna fundamentals that are crucial and must be implemented in Albanian Educative System and are regulated by law are;

The fundamental principles; every institutions should define their mission, goals and regulate the aspects of creation, organization, management, administration, financing, quality assurance in compliancy with European standards.

The institutions should have their autonomy and academic freedom. All the institutions private or public should have accreditation according to the Law mentioned above. And all institutions are compulsory to have Bologna system in Albania.

An advantage for Albanian system is ECTS system which is implemented in our Universities in accordance with European standards and makes it easier for Albanian students to transfer their studies and provides academic recognition abroad.

Also very crucial places in European standards have issues of student mobility and transparency of administration in HE's and supporting of academic research. (Dr. Tomi Treska, Dr. Erjona Canaj, 2013)

\subsection{Quality Standards of Higher Education}

ESG is the European Standards and Guidelines for Quality Assurance in European Higher Education Area. This organization is responsible for quality assurance. Albanian HE is obliged to meet Internal Quality Assurance in harmony with rules of ESG but give the autonomy to institutions for academic issues. HE Institutions public and private in Albania are allowed to determine the specification of their structure, develop systems and processes in accordance with their own goals. Quality Assurance institutions in Higher Education in Albania are Public Accreditation Agency of HE (PAAHE) and the Accreditation Council (AC). They are responsible for internal and external quality assurance. (Dr. Semiha Loca, M.A. Besa S. Xhaferi, 2011)

Quality assurance is a very important and difficult process. All the stakeholders in HE are very important part of this cycle. Albania has succeed to have internal and external bodies of QA, quality has high rate of return as the graduates will be employed and the state should look for future interest of quality improvement in higher education.

Standards and structure of the Higher Education system is based on the publications of Republic of Albania Parliament, Law N0. 9741, date 21.05.2007, "On the Higher Education in the Republic of Albania"

This law provides that all the main structures of establishment organization, administration, management, financing, quality assurance should be in compliance with European standards.

The mission of the higher education is:

a. to establish, transmit, develop, and protect knowledge through instruction, scientific research and services; develop and further advance arts, physical fitness and sports; develop and prepare highly qualified specialists and young scientists;

b. to offer possibilities to benefit from a life-long higher education;

c. to sustain the economic development at national and regional level; 
ç. to contribute in increasing democracy standards and developing the society and its youth (Article 2)

Article 3 of the law provides higher education institutions with academic autonomy and freedom. According to article 4 in Republic of Albania, Higher Education Institutions are considered; universities, academies, vocational colleges, higher education schools and interuniversity centers. "The main principles of the Law are:

- harmonization with the European higher education system and promotion of academic mobility of teaching staff and students,

- assurance of quality and efficiency of studies,

- participation of students in governance and decision-making, in particular in matters relating to teaching quality assurance,

- harmonization of teaching and scientific research and/or artistic work." (EACEA, 2012, p. 2)

Bologna Process, the main focus of this declaration was to harmonize the educative system in one framework for all the countries being part of it. Now there are 45 countries participating in it. The main elements in this system of compatibility in Bologna process are listed above and are reference of the study made from (ESAD, 2014);

\section{- European Credit Transfer System (ECTS)}

ECTS credits are assigned to a course based on the workload involved and a minimum number of credits (as defined by the curriculum) must be obtained by the student in order to graduate.

1 ECTS credit is equivalent to between 25 and 30 hours of work (including classes, individual and group work outside the classroom, assignments, exams etc.).

60 credits represent one academic year of study.

This system allows courses on a student's transcript to be recognized or transferred between different curricula.

\section{- Three-Cycle System}

The defining of the three-cycle system has allowed educations systems in different countries to map their existing educational programs to a common structure.

\section{- Competences \& Europass Diploma Supplement}

The Bologna Process aimed to bring about a shift in focus in the outputs of higher-level education, putting an emphasis on the ability to understand an issue and act rationally and ethically to resolve it. "Education is about acquiring skills, but also about acquiring values and attitudes and learning outcomes have come to be seen as an essential feature of education policies."

This is complimented by the Europass Diploma which compiles all learning achievements, official qualifications, work experience, skills and competences acquired over time, allowing a person's Lifelong Learning Portfolio to be easily understood across the EHEA zone.

\section{- Quality Assurance (Accreditations)}

The Bologna Process puts great emphasis on quality assurance.

\subsection{Accreditation and Evaluation of Higher Education Institutions}

Higher education institutions in Albania must adopt the set standards by state in order to be accredited by the Accreditation agency. In order to be in line with other European countries Albania has also the standards that should be achieved in order to have qualitative education.

Accreditation is the external recognition of quality. As the HE institutions in Albania based on the Law have autonomy in their operations, HE's are self monitoring and regulating their institutions in order to win credits in competition with other HE's when external reviews are done.

Bologna Process adoption as it was mentioned above has made a rational change in educative system in Albania and has put in to focus the quality assurance. Combination of continues work 
of the staff and governance of HE's to increase quality and the pressure of external controls is enhancing the quality day by day.

All $\mathrm{HE}$ institutions before being recognized by Accreditation agency pass through the process of self evaluation and external peer review, they are subject to it before the opening in order to assure they meet standards of quality set by Ministry of Education and Science and they have to undergo this process also during their existence in order to assure they continuously are improving their quality of education provided. Accreditation is known as recognition of an institution by public as it has met the standards set by accreditation agency. (EACEA, 2012)

"The purpose of the accreditation system of Albanian higher education institutions is to:

- Use standards of evaluation to ensure quality education;

- Encourage institutions to improve the quality of education;

- Ensure the accountability of educational institutions;

- Ensure public confidence in educational institutions.” (EACEA, 2012, p. 5)

The process of evaluation of quality is same as in UK and ENQA countries. First phase is conducted by internal control of higher education institution; second phase is performed by expert groups which are external. This process undergone in accordance with criteria, procedures and guidelines amended by PAAHE and approved by AC. (Arjan Qefalia, Arbina Totoni , 2012) In 2007 when the reorganization of educative system was made in Albania, in accordance with the law PAAHE have made the evaluation of all public Higher education institutions. They have been evaluated according to Bologna process.

The numbers of Universities and new programs during these years have been increased, in 2011 PAAHE have made another evaluation of new study programs which are licensed or in the process of licensing; they have done institutional and program evaluations.

In general in the past evaluations mostly used in Albania were evaluations of programs at departmental level. In current situations the mixed evaluations are mostly used; starting with program level and continuing with periodic evaluation which is mainly focused on institutional evaluation. The future will be based more on Internal Quality Assurance which is more related with institutional level. (p. 263)

\subsection{Challenges in reaching and harmonizing quality standards with EU HE standards}

Based on the research that have been done and in accordance with the rules, regulations and standards mentioned above we can say that Albania is approaching European standards and is implementing Bologna process. As it is obligatory for all the institutions to adopt it and all the laws and other legal acts have the same direction with European countries. But is this in practice being implemented?!

Albania as developing country is in the process of progress and enhancement also educative system is part of the developing. But being in line with European countries is still out of the league for a country as Albania. Research and Development is the main issue to be considered as it is one of the main Bologna Process parts, scientific research is the main challenge for the future quality assurance in Albania. Universities have to work very hard in order to achieve to have scientific research studies and make students capable to improve this newly formed sector in the country.

11 years after the adoption of the Bologna process Albania still has a challenge of consolidation of all the universities with three cycle system. Still there are universities implementing 4 years university diplomas. Another very crucial element in the Law is the autonomy of universities which is a very difficult obstacle to be passed, as the majority of public universities are founded by government. Student cards are another reform in process.

The main and the most difficult challenge is the improvement of controlling, monitoring and reviewing quality assurance in universities. Many public and private universities are not 
accomplishing the standards of existence and are still operating in educative market. Accreditation Agencies have to improve and enhance the process of recognition. Albania should also work hard in performance improvement of universities. External and internal quality assurance should be more strict and produce reports that mirror the reality.

Even thought we have adopted the Bologna Process in our country are many universities whose diplomas are not recognized by other Bologna countries, which become a serious problem for students that want to study abroad or transfer their studies.

Bribe is another challenge to be faced in the following years. Bribe in university exists from the high levels, where we can include the existence of university because the owner of the institution is having reciprocal interest with governing body of state. Following the bribe by including Accreditation agencies, peer review agents etc. and the last level are student-professor relations and student-university owner relations.

The following years are very challenging for Albania, but hard working of government and accreditation agencies can minimize those difficulties. The competition of private and public universities for being the first in the ranking lists is pushing them to increase the quality which effects positively in the whole educative system.

\section{Differences and Similarities in Quality Standards of UK, ENQA and Albania}

In general it can be said that the quality assurance agencies have the same rules and regulations. The difference can be seen mainly in the way they are presented to HE institutions and the control process of the institutions. The standards mainly are the same except of the wider and more detailed standards and regulations that some agencies present.

The table above presents the main characteristics of QA in ENQA countries, UK and Albania. The table puts on focus the differences and similarities in three different regions.

\begin{tabular}{|c|c|c|}
\hline ENQA/Europe & QAA/ UK & PAAHE and AC/ Albania \\
\hline $\begin{array}{l}\text { Main roots in 1994-1995, establishment in } \\
2000\end{array}$ & $\begin{array}{l}\text { Established in 1997, Follower of } \\
\text { Bologna system from } 2009\end{array}$ & $\begin{array}{l}\text { New in this field, from } 2007 \text { the QA agency } \\
\text { started operating }\end{array}$ \\
\hline $\begin{array}{l}\text { The main body of QA for all the countries } \\
\text { in EHEA }\end{array}$ & $\begin{array}{l}\text { Follower of ENQA standards, the } \\
\text { main body for controlling } 4 \text { countries } \\
\text { in UK }\end{array}$ & $\begin{array}{l}\text { Narrow in performance, just Albanian } \\
\text { territory is controlled by these agencies }\end{array}$ \\
\hline $\begin{array}{l}\text { The main vision is to include all the } \\
\text { countries and have a standardized and } \\
\text { harmonized educative system in EHEA }\end{array}$ & $\begin{array}{l}\text { The main responsibility to organize } \\
\text { and control the QA and safeguard and } \\
\text { improve the quality of education in } \\
\text { UK }\end{array}$ & $\begin{array}{l}\text { As they are follower of ENQA the main } \\
\text { goal is to be in line with other European } \\
\text { countries in implementing standards and } \\
\text { QA }\end{array}$ \\
\hline $\begin{array}{l}\text { Wider in their "future picture"; form quality } \\
\text { culture in these areas }\end{array}$ & Continuously improve the quality & $\begin{array}{l}\text { Still in the first steps of establishment of } \\
\text { quality standards and implementation in HE } \\
\text { institutions }\end{array}$ \\
\hline $\begin{array}{l}\text { Standards and guidelines are grouped in ; } \\
\text { Internal, External and external standards for } \\
\text { quality assurance agencies }\end{array}$ & $\begin{array}{l}\text { The Quality Code is grouped in; } \\
\text { academic standards, academic quality } \\
\text { and information about higher } \\
\text { education provision }\end{array}$ & In line with ENQA and Bologna Process \\
\hline $\begin{array}{l}\text { Universities are more autonomous. Not } \\
\text { very detailed standards on operating and } \\
\text { processes of work }\end{array}$ & $\begin{array}{l}\text { Very detailed standards and } \\
\text { regulations for each process in } \\
\text { universities }\end{array}$ & $\begin{array}{l}\text { Universities are independent bodies and } \\
\text { agencies are following and controlling their } \\
\text { processes }\end{array}$ \\
\hline $\begin{array}{l}\text { Evaluation Methodologies; } \\
\text { Method }\end{array}$ & $\begin{array}{l}\text { Evaluation Methodologies; mainly } \\
\text { Auditing is used }\end{array}$ & $\begin{array}{l}\text { Evaluation Methodologies; Accreditation } \\
\text { Method and partly evaluation method }\end{array}$ \\
\hline $\begin{array}{l}\text { Reviews of institutions are same for all } \\
\text { types of HE institutions they are done } \\
\text { based on Internal and external evaluations. } \\
\text { Based on categories of focus; subject, } \\
\text { program, institution or theme }\end{array}$ & $\begin{array}{l}\text { Reviews have special program for } \\
\text { each different type of HE institution. } \\
\text { Ex: Education providers, private } \\
\text { providers of education, professional } \\
\text { education providers }\end{array}$ & $\begin{array}{l}\text { Reviews of institutions are done according } \\
\text { to the categories of accreditation that they } \\
\text { are included. EX: University, colleges, } \\
\text { professional institutions. But they are done } \\
\text { in line with ENQA processes }\end{array}$ \\
\hline $\begin{array}{l}\text { Evaluation; } 4 \text { stage model, Independent in } \\
\text { their government and rules setting, internal } \\
\text { self assessment, external assessment by } \\
\text { peer-review and publication of report }\end{array}$ & $\begin{array}{l}\text { Evaluation; self evaluation, Peer } \\
\text { review and publication of report }\end{array}$ & $\begin{array}{l}\text { Evaluation; self evaluation, external peer } \\
\text { review and publication of report }\end{array}$ \\
\hline
\end{tabular}




\section{Conclusion}

The improvement and development of higher education system has been one of the main objectives of European countries after 1990's. Adoption of standards of quality and the assurance of quality in every $\mathrm{HE}$ institution has been the main goal of the accreditation agencies and Ministries of Education in all the countries.

Quality assurance in higher education is the first step toward the improvement and progress in every field of a country. Giving qualitative education to university and colleges students is the beginning of healthy economic and social life. Education is the main root of countries development.

As conclusion from the study above it can be said that ENQA and QAA in UK have been the main bodies of assuring that quality standards are being adopted from HE institutions and they have mainly achieved these goals. As the majority of countries that are part of European area are members of ENQA and have adopted the standards of quality in their education institutions. Also all the 4 countries in United Kingdom area have adopted QAA quality assurance standards in consistence with their educative system. In the other hand countries that are in their development process like Albania in our example are continuously working and auditing their educative institutions to be in line with European standards of education despite all the difficulties that arise.

To sum up the study it can be said that all the countries of Europe or UK are in search of perfection in every field that's why they are not opposing any standard, rule or regulation that is on their profit for development of their welfare in the near future or distant future.

All quality assurance agencies in general have same rules and regulation to be adopted the main difference are the processes and evolution methodologies that are specific in some countries. The main similarity of all the quality assurance agencies and countries adopting the quality standards is being careful in delivering high quality education in order to have a better generation with high standard of education. That provides us safe progress in every field; economic, social, technological and higher welfare.

\section{References}

Arjan Qefalia, Arbina Totoni . (2012). The correlation accreditation- Bologna Process- Continous quality improvment based on Professors' perception in Albanian Public Universities . Annales Universitatis Apulensis Series Oeconomica, 260-268.

Dr. Semiha Loca, M.A. Besa S. Xhaferi. (2011). Developing Standards for Internal Quality in Higher Education ( Case of Albania and Macedonia). 7th Research/Expert Conference with International Participations "QUALITY 2011", (pp. 817-820). Neum, B\&H.

Dr. Tomi Treska, Dr. Erjona Canaj. (2013). Albanian "BOLOGNA" How close/far is Albanian Higher Education to European standards? Mediterranean Journal of Social Sciences, MCSER Publishing, RomeItaly, 666-675.

EACEA, A. a. (2012). Higher Education in Albania. EACEA.

ECCTIS. (n.d.). Description of Higher Education in England, Wales and Northern Ireland. Retrieved September 2014, from ECCTIS: http://www.ecctis.co.uk/europass/documents/ds_description.pdf

Editors: Fiona Crozier, Nathalie Costes, Paula Ranne and Maria Stalter. (2010). ENQA 10 YEARS (20002010): A decade of European co-operation in quality assurance in higher education. Helsinki : European Association for Quality Assurance in Higher Education 2010.

Editors; Brigitte Lohmar and Thomas Eckhardt . (2013). The Education System in the Federal Republic of Germany 2011/2012 . Bonn: Secretariat of the Standing Conference of he Ministers of Education and Cultural Affairs of the Lander in the Federal Republic of Germany.

ESAD, /. R. (2014). ESAD. Retrieved September 2014, from ESAD: http://www.esade.edu/homepage/eng/registrar/processes-and-regulations/bologna-process

Golloshi, A. (2013). Challanges of Higher Education Quality Standards in Albania. The 1st International Conference on Research and Education - Chalenges Toward the Future (ICRAE2013) (p. 1). ICRAE2013. 
Mauro Bemardini, Francesca Ruffilli. (2006). Evaluation and accreditation in Germany: the case study of the Technische Universitat Berlin . Assessing Quality in European Higher Education Institutions, pp. 93-104.

Official Website of ENQA . (2014).

Quality Assurance Agency for Higher Education. (2005). Quality assurance in UK higher education:A guide for international readers. QAA.

Quality Assurance Agency. (2014, August). QAA. Retrieved September 2014, from QAA/UK: http://www.qaa.ac.uk/assuring-standards-and-quality/the-quality-code/quality-code-part-a

Quality Assurance Agency. (2014, August ). QAA. Retrieved September 2014, from QAA/UK: http://www.qaa.ac.uk/assuring-standards-and-quality/the-quality-code/quality-code-part-b

Quality Assurance Agency. (2014, August). QAA. Retrieved September 2014, from QAA/UK: http://www.qaa.ac.uk/assuring-standards-and-quality/the-quality-code/quality-code-part-c

Quality Assurance Agency. (2014). QAA. Retrieved September 2014, from QAA/UK: http://www.qaa.ac.uk/reviews-and-reports/how-we-review-higher-education

report, E. (2009). Standards and Guidelines for Quality Assurancein the European Higher Education Area. Helsinki, Finland : European Association for Quality Assurance in Higher Education, 2009, Helsinki,3rd edition.

Survey, E. (2003). Quality procedures in European Higher Education. Helsinki: European Network for Quality Assurance in Higher Education, 2003.

Thune, C. (2010). ENQA 2000-2005: From the launch of a professional networkto the success in Bologna of a new association. Helsinki, Finland: European Association for Quality Assurance in Higher Education 2010. 